\title{
Fish Traders of Tambaklorok
}

\author{
Nurdien H. Kistanto* \\ Program of Social Anthropology, Faculty of Humanities, University of Diponegoro, Semarang City
}

\begin{abstract}
This paper describes fish traders who live and work in Tambaklorok, north Semarang city coastal area. In accordance with the coastal environment, livelihood of many people of this area is fishing, carried out by fishermen, and accompanying activities such as selling fish, by female fish processors and/or fish traders. Based on the field data collection and reading the literature, this study aims to generate an analysis of livelihood profile of the fish traders in this community. This study employs field research method by conducting specific observation, interviews and in-depth interviews. This study finds some five fish traders as the actors of coastal environment livelihood, to be presented in this paper.
\end{abstract}

Keywords: coastal livelihood, fishing community, north Semarang City, fish traders.

\section{Introduction}

The area of Tambaklorok, is an interesting region, as it is located in the urban coastal environment, with communities that run livelihood as fishermen and activities relating to the capture and trade of fish, carried out by fish traders. The importance of the area and community of Tambaklorok is growing since it was designated as the area of "Marine Tourist Destination." The total budget reaching 47 billion IDR, were implemented to (1) the improvement of road, of 738 meters length; (2) the development of green open space; and (3) the development of traditional fish market. This project was accomplished on the $30^{\text {th }}$ of March 2019 [1,2,3,4]. This study generates analysis of fish traders as actors of livelihood [4].

\footnotetext{
* Corresponding author : nhkistanto@gmail.com
} 


\section{Fish Traders, Auction Place and Fishermen}

In Tambaklorok fish traders start to work since 6 a.m. to join the fish auction, purchasing fish and other sea-catches for resale in the fish markets. Some other fish traders are awaiting fisherman to buy the catch, containing various fish. Those fish traders who buy fish from the Fish Auction Place (Tempat Pelelangan Ikan/TPI) are those who invest much more amount of capital, since TPI only buy fish that reach the weight of 1 quintal. Smaller scale fish trader will buy fish from the fishermen. That is why many fish traders choose to wait the fishermen land from the sea and approach to pick the fish from the fishermen.

The business relationship with fish traders and fish processor is very important to the fishermen. Soon after landing from the sea, fishermen are awaited by fish traders who are standby to purchase various kinds of fish for sale in the fish markets available in Semarang city. The price is varied, depending on the size and weight of the fish or crabs, if a trader buys fish from the fisherman of Rp. $40.000 / \mathrm{kg}$, she will resale it to Rp. $60.00 / \mathrm{kg}$. Many fishermen sell the catch from the sea, direct to the traders, not through the auction place, since the catch is too little. Only catches of fish, or crabs, and shrimps or prawns that reach the weight of 1 quintal or more are sold through auctions in the TPI that take place at 7 to $11 \mathrm{am}$. Fishermen who come from other areas such as Weleri, Kendal, Demak, and Jepara, with larger fish boats, handed in the catch on the management to be auctioned that morning as well. The fish traders from the fish markets in Semarang since 6 a.m. have come to join the auction, buying fish and other sea-catches for resale in their respective markets $[5,6]$.

\section{Fish Traders \& New Fish Market}

Many fish traders are fisherman's wives. These wives usually collect fish or other kinds of catch from their husbands directly land from the sea. Basically there are two types of traders, namely (1) traders who purchase or collect fish or other kinds of catches just directly resale them in the market, and (2) traders who purchase or collect fish or other kinds of catches process them for several days, then resale them in the market afterwards, such as those processing fish to become salted fish (gereh), or shrimp to become shrimp paste (terasi), or smoked fish (mangut).

The new Tambaklorok Fish Market, was inaugurated at the end of March 2019. It is a two-storey building. When I observed there on the month of July \& August, the first floor of this market consists of 72 stalls sized of $2 \times 2 \mathrm{~m}$, arranged in 6 lines, with each line containing 12 stalls, and only 63 new stalls occupied by the traders, the rest of 9 stalls are still empty even though there are traders who rent it. Of the 63 traders, 9 traders do not sell fish but 1 sells meat and chicken, 1 sells cut-chicken, 1 sells meat, 1 sells cut-chicken and smoked fish, 1 sells chicken and quail eggs, and 3 sell chicken and nine staples of food (sembilan bahan pokok pangan or sembako). In addition, there are 5 fish traders selling outside the market building but still inside the market complex and 5 merchants held their trades outside the market complex, on the roadside. On the 2 nd floor of the fish market is an open space without a partition of stalls, occupied by the sellers of vegetables and fruits, which have not even counted the fingers of the 2 hands. 
Merchant schedules vary, some start selling at 6 or 7 a.m. to 1 or 2 noon, some are just coming at 2 noon when some traders want to go home, but some are selling until 4, 5, and 6 p.m.. The vendors who occupy the stalls in the fish market are subject to rent Rp. 3500/day, security charge Rp. 5000/day, and cleaning-waste charge Rp. 2000/day. The merchants in the fish market sell fresh fish and other sea products directly from newly landed fishermen or from TPI, through auctions.

\section{Three Fish Traders}

\subsection{Khumaidah}

Khumaidah, 45, was a cooked blue crab (rajungan) trader, wife of a blue crab fisherman, Abdul, 45. Since 7 (seven) years ago, she processes and sells blue crabs to an export factory in Demak. She collects blue crabs from fishermen who sell this kind of catch to her. Depending on the size of the crabs, the price could be as low as Rp. $25.000,-/ \mathrm{kg}$ to as high as Rp. $40.000,-/ \mathrm{kg}$. Selling to the export factory, cooked blue crab can be purchased as high as Rp. 200.000 ,- to Rp. $250.000,-/ \mathrm{kg}$. This business commodity also depends on the value of USD to rupiah.

\subsection{Khodijah}

Khodijah, 55, is the chairperson of micro business organization and smoked fish group of "Mina Asri." His husband, Suhartono, 55, is an active fisherman. She run the business of smoked fish since 30 years ago, with only one assistant. Initially she participated in the fish smoking assisting her mother-in-law, she said: "The recipe of this smoked fish that I sell was from my mother-in-law, it is a bequest recipe of smoked fish." Even in 2018 she was invited to Jakarta to participate in a seminar on developing small scale business, which was paricipated by 9 activists on smoked fish processing and business. "When I was invited to Jakarta to participate in the seminar all was paid by govenment, including transportation and inn.

As for the business, she bought head of raw fish such as patin Rp. 16.500,-/kg and sell this smoked head for Rp. 30.000,-/kg, while total capital including gas and coconut shell could be Rp. 500.000,-/day with the profit of around Rp. 150.000 ,- to Rp. 200.000,- per day.

\subsection{Jamitul Aliyah}

Jamitul Aliyah, 30, is a fish broker or agent since 4 years ago. She comes from Demak of about $25 \mathrm{~km}$ from Tambaklorok, buying blue crab and fish 'Sembilang' from fisherman and selling these commodities to customers at fish market. Herself is customer of Sribuana who collects blue crabs from his husband, a fisherman. Aliyah said, "I bought raw blue crab from fishermanat the price of Rp. 35.000,- per $\mathrm{kg}$ and sold boiled blue crab Rp. 44.000 ,- per $\mathrm{kg}$. Per day sometimes I sold blue crabs to $40 \mathrm{~kg} / \mathrm{day}$. At another time I bought 'Sembilang' for Rp. 23.000,- from fisherman and sold this fish for Rp. 26.000,- to customers." She continues, "Alhamdulillaah it was enough, if I raise the price my customer will not buy fish from me again."*** 


\section{References}

1. Semarangpos.Com. 2018. "Pemprov Jateng Rancang Kampung Bahari Terintegrasi TPI," 22 Oktober 2018.

2. Tribun Jateng.com. Senin, 25 Februari 2019. 05:31.

3. A. Fama. "Komunitas Masyarakat Pesisir di Tambak Lorok, Semarang," Jurnal Kajian Kebudayaan Sabda Vol. 11, No. 2 (2016)

4. Koentjaraningrat. Kebudayaan, Mentalitas dan Pembangunan. Jakarta: Gramedia. (1974)

5. Kusnadi. Pembangunan Wilayah Pesisir Terpadu. Yogyakarta: Graha Ilmu. (2015)

6. Mubyarto, Loekman Soetrisno, Michael Dove. Nelayan dan Kemiskinan: Studi Ekonomi Antropologi di Dua Desa Pantai. Jakarta: Rajawali. (1984) 